\title{
Assessment on Dairy Production System and its Constraints in Horoguduru Wollega Zone, Western Ethiopia
}

\author{
Belay Beyene $^{1^{*}}$, Demissu Hundie ${ }^{1}$ and Geleta Gobena ${ }^{2}$ \\ ${ }^{1}$ Faculty of Agriculture, Department of Animal Science, Wollega University, \\ Shambu Campus, Shambu, Ethiopia \\ ${ }^{2}$ Horo Guduru Animal Production and Research Center, Wollega University, Guduru, Ethiopia
}

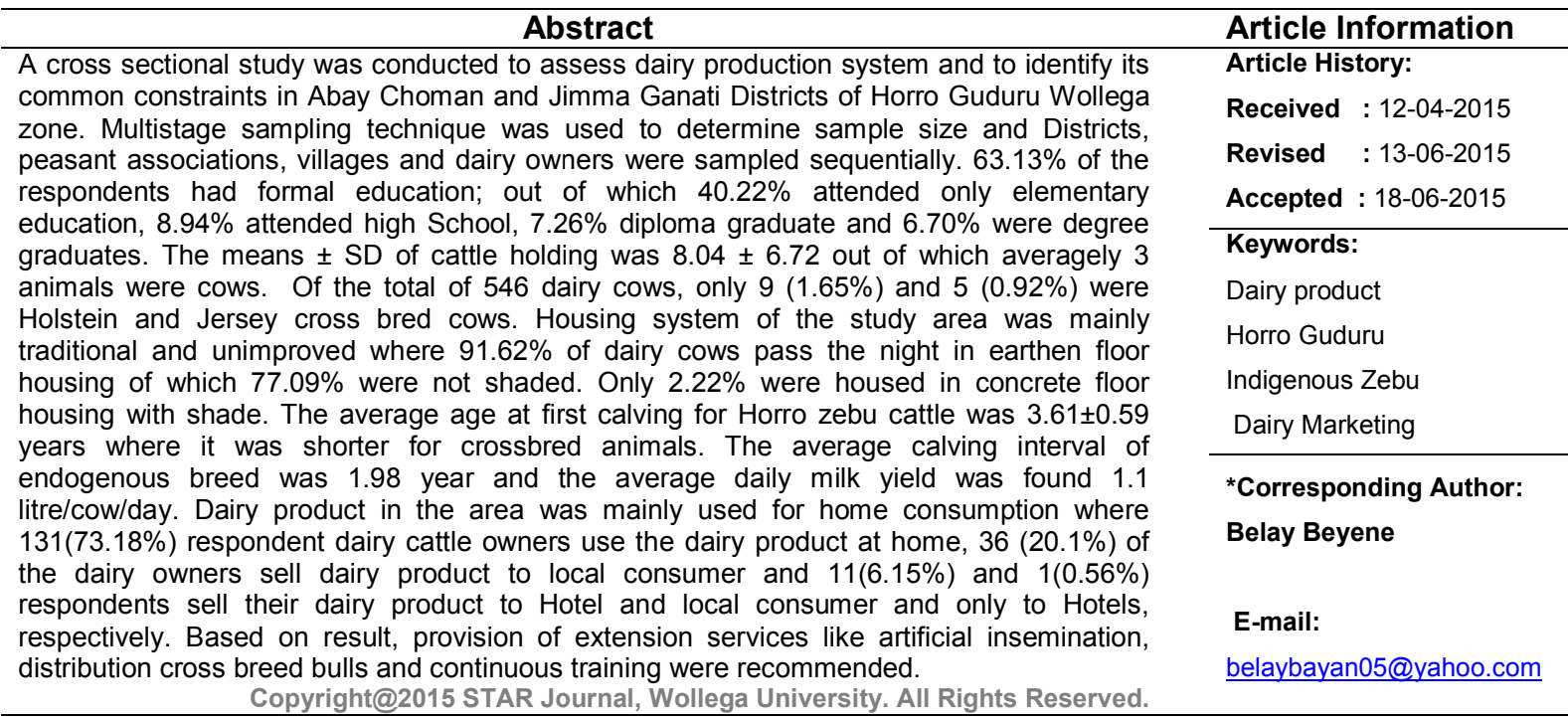

\section{INTRODUCTION}

Agriculture is the most employment industry in the world it employed $42 \%$ of the worlds' population and more than $50 \%$ of developing countries population (Upton and Otte, 2004). Livestock are the sub sector of agriculture. Like other developing countries, agriculture is main stay of Ethiopian economy. Ethiopian livestock population is estimated to be 55.03 million cattle, 27.35 million sheep, 28.16 million goats, 1.96 million horses, 6.95 million donkeys, 0.36 million mules, and about 1.1 million camels and 51.35 million poultry (CSA, 2013). In Ethiopia livestock contribute $30-40 \%$ of Agricultural Growth Domestic Product (GDP), $16-20 \%$ of national GDP and $14-16 \%$ of foreign exchanges; however shortage of feeds, livestock disease, poor management practice, poor genetic improvement and lack of organized marketing system are the major constraint that hinder the profitable production of livestock in Ethiopia (Gebregziabhare, 2010). Livestock performs multiple functions in the Ethiopian household economy by providing food, input for crop production and soil fertility management, cash income and cash saved, fuel, social functions, and employments (USAID, 2010).
In Ethiopia, dairy production is one of the sub-sectors of livestock production that contributes to the livelihood of the owners through important sources of food and income; even though dairying has not been fully exploited and promoted in the country (Yigrem et al., 2008). FAO (2004) reported the average milk intake of Ethiopia is 17lt per capita which is below estimated standard for African per capita consumption. Horro-Guduru Wollega zone is located in Oromia Regional States in the western part of Ethiopia where mixed crop livestock production is dominant agricultural practice. The area is the sources of indigenous Horro cattle and sheep breed where these animals are named after the name of Horro District. However, the dairy potential and production opportunity and production challenges of Horro cattle did not studied in detail. Problem appraisal from the society indicates feed shortage, livestock disease and access to market and fluctuation of market in dairy production were the hindering factor for the dairy production in the area. On the other hand, many studies and projects conducted in the country were focused in the central parts of the country. Therefore; the current study was conducted at 
Belay Beyene et alo,

Abayi choman and Jimma Ganati districts to (1) asses Dairy cattle management system and feeding practice in dairy, (2) identify the milk production and marketing methods used and (3) determine and prioritize common dairy production constraints

\section{MATERIAL AND METHODS}

\section{Description of the Study Area}

Horro Guduru Wollega zone, is located at about 314 $\mathrm{km}$ west of Addis Ababa (the capital of the country), with geographical coordinates of $09^{\circ} 29^{\prime} \mathrm{N}$ and $37^{\circ} 26^{\prime} \mathrm{E}$, and at an altitude of approximately 2,296 m.a.sl. Mixed crop-
Sci. Technol. Arts Res. J., April-June 2015, 4(2): 215-221

livestock agriculture is the main stay in the area. The area has one long rainy season extending from March to midOctober with annual rainfall ranging from $1000-2400 \mathrm{~mm}$ (Olana, 2006). The monthly mean temperature varies from $14.9{ }^{\circ} \mathrm{C}$ to $27{ }^{\circ} \mathrm{C}$. The area is favorable for multi disciplinary agricultural activities and livestock and fishery production. Farmers in Horo Guduru Wollega zone of Oromia state lead their livelihoods by mixed croplivestock production system. In this study two districts was selected based on exist of livestock, dairy production experience, access for data collection and representative of the area.

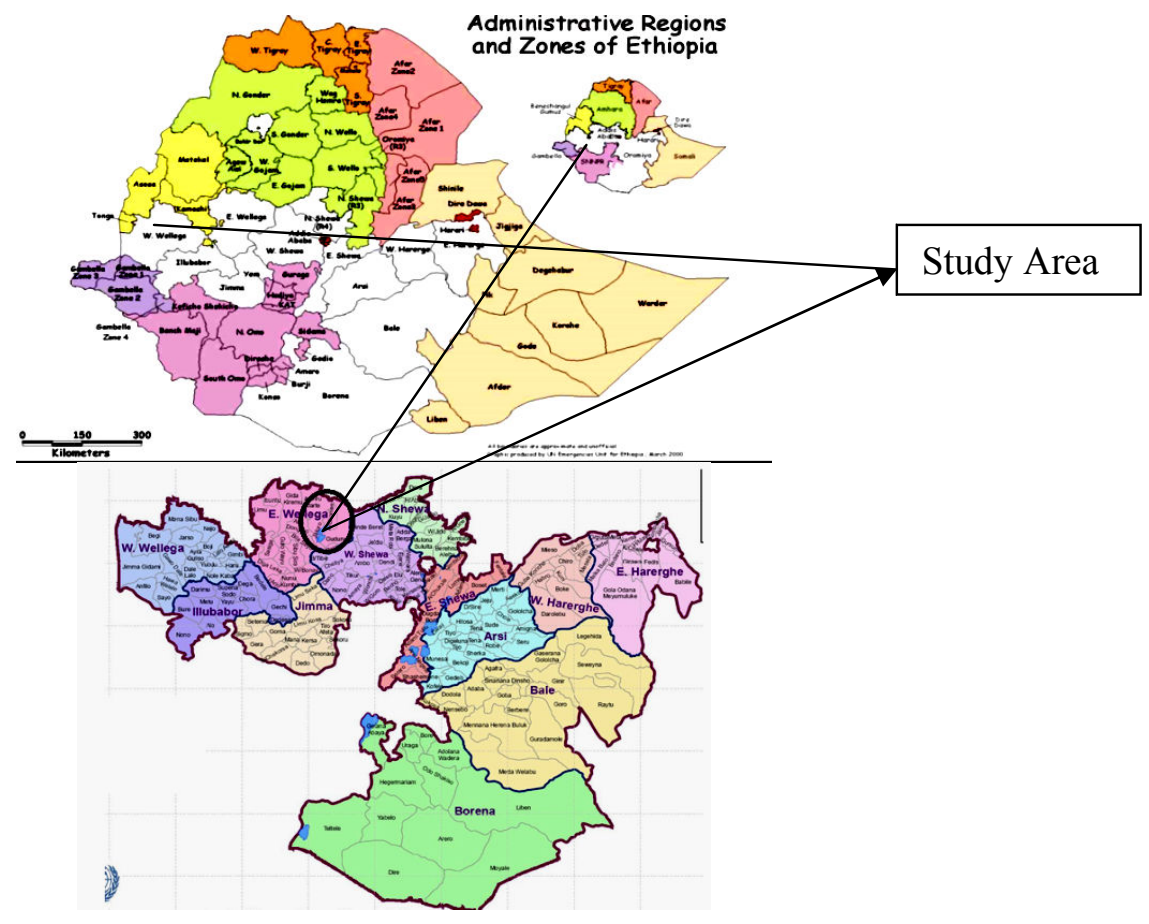

Figure 1: Map of study area

Study Design, Sampling Technique and Methods of Data Collection

A cross sectional study was conducted to assess dairy production system and identify the common problem in dairy production in Abay Choman and Jimma Ganati Districts. Multistage sampling technique was followed to determine sample size. Districts, peasant associations, villages and dairy owners were sampled sequentially. Zone was purposively selected because of high cattle population, high dairy cattle producer smallholders and the socio-economy of the society was highly dependent on crop-livestock production and marketing. From each district, three peasant associations were included and from each peasant association four villages were included. After the complete list of family head who owned cattle was obtained from kebele administration, 7-8 dairy owners per village were included (Dohoo et al., 2003). The total farmers sample size was 179 household.

Structured and semi-structured questionnaire was administered to dairy owners' to collect data on herd and individual animal productivity, socio-economic role of dairy production during each visit. Information on management practices, productivity, use of Artificial Insemination and common constraints of dairy production in the area was collected.

\section{Data Management and Analysis}

Collected data were entered into MS Excel spreadsheet (Excel, 2007) for clearance of data. Descriptive statistics and percentage were analyzed using Excel spread sheet and Statististical Program for Social Sciences (SPSS) Version-20 software. Chi-square was used to identify the level of significance between dependant and independent variables. Mean and standard deviation were used to analysis the herd structure and reproductive performance of local and cross breeds. In all cases, the 95\% confidence interval and the $5 \%$ level of significances can be used to declare the significant difference.

\section{RESULTS AND DISCUSSION}

Livestock Production and their role in the Socioeconomy of Study Area

The smallholders' education level, Age and sex of the householders, the family size and household characteristics are indicated in Table 1. It depicted 
Belay Beyene et alo,

$63.13 \%$ of the respondents had formal education; out of which $40.22 \%$ attended elementary education, $8.94 \%$ attended high School, $7.26 \%$ diploma graduate, $6.70 \%$ were degree graduates. In the current study, $74.9 \%$ of the
Sci. Technol. Arts Res. J., April-June 2015, 4(2): 215-221

family leaders were male while $25.1 \%$ household heads were female. This study also indicated the mean family size was found 6.77 person/households.

Table 1: Socio economic characteristics of smallholders in Abay Choman and Jimma Ganati Districts

\begin{tabular}{lccc}
\hline Parameter & Frequency & Percentage & Cl 95\% \\
\hline Education Level & & & \\
Informal Education & 66 & 36.87 & $31.47-42.21$ \\
Elementary(1-8) & 72 & 40.22 & $34.33-46.11$ \\
High School(9-12) attendant & 16 & 8.94 & $7.63-10.25$ \\
Diploma graduate & 13 & 7.26 & $6.20-8.32$ \\
Degree Graduate & 12 & 6.7 & $5.72-7.68$ \\
\hline Occupation & & & \\
Mixed Crop-livestock production & 147 & 82.1 & $70.07-94.13$ \\
Livestock production only & 32 & 17.9 & $15.28-20.52$ \\
\hline Purpose of Livestock rearing & & & \\
Drought and manure & 6 & 3.35 & $2.86-3.84$ \\
Meat, milk, draught and Manure & 154 & 86.03 & $73.43-98.63$ \\
Milk production only & 19 & 10.61 & $9.06-12.17$ \\
Male & 134 & 74.9 & $63.93-85.87$ \\
Female & 45 & 25.1 & \\
Parameter & 179 & Mean & SD \\
Family size & 179 & 6.77 & 2.43 \\
Age & Number of respondent & 40.84 & 13.43 \\
\hline
\end{tabular}

According to this study the highest percentage of householders' educational level falls in the Elementary School and informal education level that accounts for about $40.22 \%$ and $36.87 \%$, respectively. Similar results were reported by (Belay et al., 2014; Bereda et al., 2014) from Dandi District, Oromia Regional State in Central Ethiopia and Ezha Districts of the Gurage Zone in Southern Ethiopia, respectively. These low education levels of the society are the challenges on modernization of dairy production and commercialization of dairy product that requires a continuous training to enable the dairy productivity to move forward. The mean and standard deviations of family size of the study area was $6.77 \pm 2.43$ which is slightly in agreement with the finding of Bereda et al., (2014) who reported average family size of $6 \pm 0.18$ and Belay et al. (2012) which reported a mean family sizes per household to be six (6). The finding of mean family size of Somali region of Ethiopia 6.65 and 6.2 in rural and urban respective reported by Birhan, (2013) also agrees with the current result. The large family size is an opportunity for improving dairy production with respect to labor provision in cattle herding, husbandry, calve rearing and dairy product processing and marketing. Eighty six percent of the interviewed respondents reported the reason for cattle rearing that was mainly for meat, milk, plowing land and manure. These confess the research finding reported on the practices of mid-highland and highlands of Ethiopia where cattle rearing was aimed for multipurpose uses (Laval and Assegid, 2002; Yigezu, 2003).

As it could be referred from (table-1), the occupation of the respondents $(82.1 \%)$ smallholders lives by mixed crop-livestock production farm activity. According to Negassa et al. (2011) report, the mid and highland farmers incorporate small scale dairy production with crop farming with the objective of using dairy animal for dairy production and giving birth to replacement stock and draft (oxen). However, the report of Birhan (2013) in Somali region of Ethiopia was in contrary to the current study result.

\section{Cattle Herd structure}

The cattle herd structure of the study area is indicated in (Table-2). The total population of cattle reared by 179 (households sampled for the study area) were 1440; of which 546 were dairy cows which accounts for about $37.92 \%$ of total cattle population. This study showed that the means \pm SD of cattle holding was $8.04 \pm 6.72$ out of which averagely 3 animals were dairy cows. Of the total of 546 dairy cows, only $9(1.65 \%)$ and $5(0.92 \%)$ were Holstein and Jersey cross bred cows, respectively. This implied that, $97.43 \%$ of dairy cows were purely local breeds.

Table 2: Cattle herd structure of Abay Choman and Jimma Ganati Districts

\begin{tabular}{llll}
\hline Study Variables & Total Cattle & Mean cattle holding & SD \\
\hline Cattle Population & 1440 & 8.04 & 6.72 \\
Dairy Cow & 546 & 3.07 & 2.85 \\
Lactating Cow & 308 & 1.72 & 1.27 \\
Local Dairy Breed Cows & 305 & 1.74 & 1.25 \\
Holstein Cross Dairy Cattle & 9 & 0.05 & 0.31 \\
Jersey Cross Dairy Cattle & 5 & 0.03 & 0.196 \\
\hline
\end{tabular}


Belay Beyene et alo,

The means and SDs $(8.04 \pm 6.72)$ of cattle holding per households was much lower than the 17.5 and17.0 average cattle head/ households reported by Laval and Assegid (2002) for Boji districts and (Demissu et al, 2013) for Guduru districts respectively, in western Ethiopia. On the contrary the per household cattle holding of the current study was higher than the report from Shashemene-Dilla area of Southern Ethiopia which reported in the crop based mixed system average herd size/ household was $3.8 \pm 0.42$ (Yigrem et al., 2008). However, the mean cattle holding of this study was in line with 7.73/households herd size report from Bahirdar zuria of north Ethiopia (Asaminew and Eyassu, 2009). The variation in cattle herd size/households in different parts of the country at different districts might be due to the difference in per household land holding, variation in human population density, the variation in function of cattle in different areas and existence of communal grazing land. The means and standard deviations of (1.72 \pm 1.27 ) lactating cow/households found by the current study was slightly comparable with average herd size of 1.4/household reported from Gurage zone of southwestern Ethiopia (Bereda et al., 2014). It was higher than the 1.1, 1.2 and 1.1 milking cow holding reported by Bahirdar Zuria of North Ethiopia (Asaminew and Eyassu, 2009), Mekonin (2006) and Nebiyu (2008) in Delbo
Sci. Technol. Arts Res. J., April-June 2015, 4(2): 215-221

watershed area and Asrat et al (2015) around Bodity, Southern Ethiopia respectively. However, the average milking cow holding was lower than the 3.2, 3.1 and 2.2 mean holding reported by Lemma (2004) for Adami Tulu Jido Kombolcha, Arsi Negele and Lume districts, respectively and Tesfaye (2007) who reported (3.0 \pm 0.15$)$ holding in Metema district of North Western Ethiopia. In this study out of the total of 546 dairy cows only 9 Holstein crosses and 5 Jersey cross cow were found. This implies low level of extension services, insufficient crossbred heifer resource available and unsatisfactory $\mathrm{Al}$ service delivery

\section{Housing and Feeding Management}

According to this assessment $91.62 \%$ of dairy cows pass the night in earthen floor housing of which $77.09 \%$ were not shaded. Only $2.22 \%$ were kept in concrete floor housing with shade (Table-3). The study also showed that during the dry season $93.85 \%$ of the dairy producers were providing supplementary feeds to their animals in addition to grazing on field. However, during the wet season only $21.23 \%$ respondents stated that they were proving supplementary feed while $78.77 \%$ respondents were solely dependent on grazing. Out of the total respondents of the study, $84.45 \%$ were supplying crop residues as supplementary feeds.

Table 3: Housing and Feeding management of Dairy Cows in Abay Choman and Jimma Ganati

\begin{tabular}{lcccc}
\hline \multicolumn{1}{c}{ Study Parameters } & $\mathbf{N}$ & $\%$ & $\mathbf{9 5 \%} \mathbf{C l}$ & P-Value \\
\hline Housing Management & 26 & 14.53 & $12.4-16.65$ & $\mathrm{P}<0.001$ \\
Earthen floor with shade & 138 & 77.09 & $11.3-88.39$ & \\
Fence barn without shade & 11 & 6.15 & $5.25-7.05$ & \\
Stone bedded floor with shade & 4 & 2.23 & $1.90-2.56$ & \\
Concrete made floor with shade & $\mathbf{N}$ & $\mathbf{4}$ & $\mathbf{9 5 \%} \mathbf{C l}$ & $\mathbf{P}$-Value \\
Dry Season Feeding management & 20 & 11.17 & $9.53-12.8$ & $\mathrm{P}<0.001$ \\
\hline Feed Supplement & 123 & 68.72 & $58.65-78.78$ & \\
\hline Hay and crop residues with grazing & 6 & 3.35 & $2.86-3.84$ & \\
Crop residues with grazing & 11 & 6.15 & $5.24-7.04$ & \\
Crop residue and Atela & 2 & 1.12 & $0.95-1.28$ & \\
Grazing only & 17 & 9.50 & $8.11-10.88$ & \\
Atela, hay, crop residues and grazing & & & & \\
Hay with grazing & $\mathrm{N}$ & $\%$ & $95 \% \mathrm{Cl}$ & $\mathrm{P}-\mathrm{Value}$ \\
Wet season Feeding management & 141 & 78.77 & $67.23-90.31$ & $\mathrm{P}<0.001$ \\
Feed Supplement & 34 & 18.99 & $16.21-21.78$ & \\
Grazing Only & 3 & 1.68 & $1.43-1.92$ & \\
Grazing, and crop residues & 1 & 0.56 & $0.47-0.64$ & \\
Gazing and Hay & & & & \\
Grazing and improved forage & & & \\
\hline
\end{tabular}

The housing system of dairy cows found in the current study was mainly fence barn with earthen ground where $77.09 \%$ of respondent householders' cattle were kept in unsheltered fence and $22.91 \%$ of dairy cows were living in shaded house. However, only $14.53 \%$ and $6.15 \%$ householders had prepared stone and concrete bedded floor housing with shade for their animals. The finding of this study disagrees with the finding of (Belay et al., 2014) who reported $60 \%$ of householders keep their animals during nighttime in sheltered housing. The variation in housing practices might be because of the difference in awareness of the farmers and the special difference and the use of cows dung directly for crop field fertilization in the study area by changing barn in few weeks' difference.

Feed supplementation was commonly practiced during dry and wet season of the year however; there was a variation in the type feed supplemented. The study revealed use of grazing pastureland during dry and wet season had similarly utilized where communal grazing land was the mainstay for all livestock in all seasons; though the variation was with supplementary feed provided for cattle based on their productive stage and function. During dry season 168 (93.85\%) of the respondents provide additional feed for their cows but 143 $(78.77 \%)$ of the respondents reported that the source of their animals' feed during wet season was solely grazing on natural pasture. The major supplementary feed of livestock according to this study was crop residue which accounts for about $89.38 \%$ and $18.99 \%$ for the dry and wet seasons of the year, respectively (Table 3 ). The result of the current study agrees with the sample survey report that indicates the major sources of feed for livestock in sedentary production were natural pasture grazing $57.13 \%$, crop residue $29.29 \%$, Hay $7.24 \%$ and byproducts $1.17 \%$ (CSA, 2013) and a study report from 
Belay Beyene et al.,

Gurage zone of south western Ethiopia where grazing covers $56.7 \%$ and $16.7 \%$ supplementary feed was crop residues (Bereda et al., 2014) which implies that major fed supplement was crop residue.

\section{Cattle Breeding and Production management}

As indicated on (Table 4) below, of the total respondent householders (179), 167(93.3\%) respondents were practicing natural mating on cattle rearing. The study
Sci. Technol. Arts Res. J., April-June 2015, 4(2): 215-221

revealed that average age at first calving for Horro zebu cattle according to the owner opinion study was 3.6 years. The result indicated the average calving interval of endogenous breed was 1.98 year. The average daily milk yield studied for these cattle was 1.1 litre/cow/day. As indicated on (table 4) crossbred dairy cows on average required 2.98 year for $1^{\text {st }}$ calving and 1.23 year between consecutive calving.

Table 4: Breeding Methods used and Breeding Characteristics of Dairy cows of the study area

\begin{tabular}{|c|c|c|c|c|}
\hline Breeding Methods & $\mathbf{N}$ & $\%$ & $95 \% \mathrm{Cl}$ & P-Value \\
\hline Natural Mating & 167 & 93.3 & $79.63-106.96$ & $\mathrm{P}<0.001$ \\
\hline Artificial Insemination & 7 & 3.9 & $1.01-6.79$ & \\
\hline Both & 5 & 2.8 & $0.34-5.25$ & \\
\hline \multicolumn{5}{|c|}{ Reproductive Characteristics of dairy cows } \\
\hline & \multicolumn{4}{|c|}{ Breed of cattle } \\
\hline \multirow[t]{2}{*}{ Parameter } & \multicolumn{2}{|c|}{ Local Zebu } & \multicolumn{2}{|c|}{ Crossbred } \\
\hline & Means & SD & Means & SD \\
\hline Age at first calving & 3.61 & 0.59 & 2.98 & 0.81 \\
\hline Calving Interval & 1.98 & 0.48 & 1.23 & 0.14 \\
\hline Number of calves/cow & 6.12 & 1.6 & & \\
\hline Milk yield/day & 1.1 & 0.03 & 8.7 & 2.54 \\
\hline
\end{tabular}

According to this assessment, $93.3 \%$ of the respondent were using natural mating and $7(3.9 \%)$ and $5(2.8 \%)$ use artificial insemination $(\mathrm{Al})$ and both natural mating and $\mathrm{Al}$, respectively. The result of this study is in line with the review on dairy production in Ethiopia that indicated smallholder producers lack the required technological, organizational as well as institutional capacities by (Yilma et al., 2011).

In the current study means and SD of age at fist calving (AFC) for local breed heifers was found $3.61 \pm 0.59$ year which was shorter than the 4.8 and $48.9 \pm 8.20$ report from Bahirdar zuria district of Northern Ethiopia by (Asaminew and Eyassu, 2009) and Guduru district of Oromia regional state in Western Ethiopia (Demissu et al, 2013), respectively. The mean and SD calving interval of local breed found by the current study was $1.98 \pm 0.48$ year. This result is slightly in line with the 24 months report for calving interval in Dandi district of west Shoa zone of Ethiopia (Belay et al., 2014). Same author reported the long calving interval reduce yearly production cycle and the amount of milk a cow likely to produce in a given period of time. The length of calving interval is associated with environmental factors, type and amount of nutrition, housing system and breeding systems experienced.
The average daily milk off-take excluding calf consumption found in the current study for local Horro breeds of zebu cows was $1.1 \mathrm{~L} /$ day. This finding is in agreement with the report of Laval and Assegid (2002) who reported daily milk off take 1.18 litre in Horro cattle breed at Boji district of west Wollega zone and 1.371litre Daily net milk yield from sedentary production system reported for different part of Ethiopia by (CSA, 2013). The mean 2.98 and 1.23 year average age at first calving and average calving intervals found by the current study is in agreement with the 34.8 month and 372.8 days report for age at first calving (AF) and calving interval $(\mathrm{Cl})$, respectively by Hunduma, (2013).

\section{Importance of Dairy production}

In the current study, 131(73.18\%) respondent dairy cattle owners use the dairy product for home consumption where $36(20.1 \%)$ of the dairy owners sell dairy product to local consumer. $11(6.15 \%)$ and $1(0.56 \%)$ respondents reported that they sell their dairy product to Hotel and local consumer and only to Hotels, respectively. The result also depicted that majority of the producers 135 $(75.42 \%)$ have experienced selling butter. The effect of season on marketing showed that the cost of dairy product significantly decrease during the summer season.

Table 5: Dairy product consumption and Marketing in Abay Choman and Jimma Ganati

\begin{tabular}{|c|c|c|c|c|c|}
\hline \multicolumn{2}{|c|}{ Producers preference and dairy marketing } & $\mathbf{N}$ & $\%$ & $\mathrm{Cl95 \%}$ & \multirow{2}{*}{$\begin{array}{l}\text { P-value } \\
\mathrm{P}<0.001\end{array}$} \\
\hline • & Sell to local consumer & 36 & 20.11 & $17.17-23.06$ & \\
\hline$\bullet$ & Use for home consumption & 131 & 73.18 & $62.46-83.90$ & \\
\hline & Sell to hotels & 1 & 0.56 & $0 . .48-0.64$ & \\
\hline - & Sell to both hotel and consumer & 11 & 6.15 & $5.24-7.05$ & \\
\hline \multicolumn{2}{|c|}{ Dairy product available on local market } & $\mathbf{N}$ & $\%$ & $\mathrm{Cl95 \%}$ & P-value \\
\hline • & Butter only & 135 & 75.42 & $64.37-86.46$ & $\mathrm{P}<0.01$ \\
\hline • & Milk and butter & 44 & 24.58 & 20.98-28.18 & \\
\hline \multicolumn{2}{|c|}{ Respondents opinion on Milk cost declining } & $\mathbf{N}$ & $\%$ & $\mathrm{Cl95 \%}$ & P-value \\
\hline$\bullet$ & Summer & 117 & 65.36 & $55.79-74.94$ & $\mathrm{P}<0.001$ \\
\hline & Winter & 52 & 29.05 & 24.79-33.31 & \\
\hline$\bullet$ & No variation & 10 & 5.59 & $4.77-6.40$ & \\
\hline \multicolumn{2}{|c|}{ Common Dairy Production Problem by Rank } & \multicolumn{2}{|c|}{ First } & Second & Third \\
\hline \multicolumn{2}{|l|}{ Disease } & \multicolumn{2}{|c|}{$39(21 \%)$} & 135(75.4) & $5(2.8)$ \\
\hline \multicolumn{2}{|c|}{ Feed shortage } & \multicolumn{2}{|c|}{$138(77.1 \%)$} & $39(21.8 \%)$ & $2(1.12 \%)$ \\
\hline \multicolumn{2}{|l|}{ Market } & \multicolumn{2}{|c|}{$2(1.12 \%)$} & $4(2.23 \%)$ & $173(96.65 \%)$ \\
\hline
\end{tabular}


According to this assessment $73.18 \%$ of the respondent reported that their dairy production was for home consumption purpose. This research report therefore, agrees with the report of (Yilma et al., 2011) whose report implies that $85 \%$ of dairy product in Ethiopia is used for household consumption. Commercialization of milk requires the processing of dairy product and access to market. However, in the study area there was no modern dairy processing and milk collection enterprise and its products were therefore marketed at local and village markets. The most marketable product was butters where fresh milk and other dairy products were rarely marketed.

Concerning milk product's seasonal market variation $65.36 \%$ of the respondents reported that the cost of dairy product gets higher during the dry season while $29.05 \%$ households responded the opposite which means milk and dairy product cost gets higher during the summer however, $5.59 \%$ of respondents reported that they do not observe significant variation. The result of the current study is in agreement with study conducted in 2001 in Boji district in the western Ethiopia that reported the price of butter (the commonly marketable dairy product in the area) reach peak during April and low in November (Laval and Assegid, 2002).

In these sedentary extensive production systems, feed is the 1st ranked constraints for improvement of production. $138(77.10 \%)$ of the respondent were ranked feed as a high shortage. Livestock diseases were ranked the $2^{\text {nd }}$ problem in dairy production. $174(97.2 \%)$ were ranked marketing the third issues in dairy production. The study showed feed shortage, livestock disease and market are the common problems in dairy production in the study area. $77.1 \%, 75.4 \%$ and $96.655 \%$ of the respondent ranked feed shortage; livestock disease and market are the top ranked three constraints respectively. Similar result was reported as feed shortage and animal health are the common problem in west shewa (Belay et al., 2012).

\section{CONCLUSIONS}

The assessment showed that most of the respondents had no formal education and the education level of those who were educated fall under elementary education. The low level of educational back ground led the dairy producers to poor animal management and reluctance to accept newly released technologies. Cattle management system in the area was extensive crop livestock production system where grain crop production was the major activity where cattle were reared as an integral sub sector. The housing and feeding systems were not improved where the major housing system used was open fence barn at back yard and communal grazing land utilization was the most commonly used feeding system especially during summer season. The commonly used feed supplements were crop residue where attela (Local brewery's left over), improved forage, grass hay and grain left over were rarely supplemented. Milk and milk products were mainly used for home consumption where butter was the major product sold to informal market. No dairy processing plants and milk collection centers were found in the zone and neighboring towns. Traditional taboo, lack of attractive market access and poor dairy cows' milk productivity discourages dairy producers not to improve their productivity. Inefficiency of Al service and insufficiency of hybrid heifer distribution boosted with farmers' reluctance to adopt new technologies had affected the productivity and reproductive performance of the existing local breed of animals and contributed to the existence of crossbred cows in few numbers. From the study it may be recommend that, the sustainable, participatory and practical trainings shall be provided for farmers in the area, where the activity undertaken by extension agents need to be strengthened by capacitating DAs (Development Agents) of respective districts, Dairy cooperatives need to be established in the milk shed that may support the dairy production activity by supplying supplementary feed, forage seeds and seedlings, veterinary drug and equipments and technologies of dairy processing and extension services, Al services, improved breed bulls center establishment and hybrid heifer distribution need to be in place for better productivity and to improve reproductive performance of locally existing dairy cattle.

\section{Acknowledgments}

The authors are greatly thankful to Wollega University for providing financial support. The authors appreciate the support and understanding of Abay choman and Jimma Ganati dairy producers. Our especial thank has goes to the staff of Agency of Livestock resources and health office of Abay choman and Jimma Ganati Districts.

\section{Conflict of Interest}

Conflict of interest none declared.

\section{REFERENCES}

Asaminew, T. and Eyassu, S. (2009). Smallholder Dairy Production System and Emergence of dairy Cooperatives in Bahir Dar Zuria and Mecha Woredas, Northwestern Ethiopia. World Journal of Dairy \& Food Sciences 4(2): 185-192.

Asrat Ayza., Zelalem Yilma and Ajebu Nurfeta, (2013). Characterization of milk production systems in and around Boditti, South Ethiopia, Department of Animal and Range Sciences, School of Agriculture, Madawalabu University, Bale-Robe, Ethiopia.

Belay, D., Azage, T. and Hegde, B.P. (2012). Smallholder Livestock Production System in Dandi District, Oromia Regional State, Central Ethiopia. Global Veterinaria 8(5): 472-479.

Bereda, A., Yilma, Z. and Nurfeta, A. (2014). Dairy Production System and Constraints in Ezha Districts of the Gurage Zone, Southern Ethiopia. Global Veterinaria 12(2): 181-186.

Birhan, M. (2013). Livestock Resource Potential and Constraints in Somali Regional State, Ethiopia. Global Veterinaria 10(4): 432-438.

CSA (Central Statistical Agency of Ethiopia), (2013). Federal Democratic Republic of Ethiopia, Central Statistical Agency. Agricultural sampling Survey: Livestock and Livestock characteristics. 505 statistical Bulletin, Addis Ababa, Ethiopia. 35-40 pp.

Demissu, H., Fekadu, B. and Gemeda, D. (2013). Early Growth and Reproductive Performances Horro Cattle and their F1 Jersey Crosses in and around Horro-Guduru Livestock Production and Research Centre, Ethiopia. Science, Technology and Arts Research Journal 2(3): 134-141.

Dohoo, I., Martin, W. and Stryhn, H. (2003). Veterinary Epidemiologic Research. AVC Inc. Charlottetown, Canada. 53-81, 335-369 pp. 
Belay Beyene et al.,

FAO(Food and Agricultural Organization), (2004). Food and Agricultural organization Livestock sector brief livestock information, sector analysis and policy branch, Rome. 2p.

Gebregziabhare, B. (2010). An over view of the role of Ethiopian livestock in lively hood and Food safety. Ministry of Agriculture and Rural development of Ethiopia; Presented on dialogue on livestock, food security and sustainability, a side event on the session of 22nd FAO, Rome. $2 p$.

Hunduma, D. (2013). Reproductive performance of crossbred dairy cows under smallholder condition in Ethiopia. African Journal of Dairy Farming and Milk Production 1(5): 101-103.

Laval, G. Assegid, W. (2002). Traditional Horro Cattle Production in Boji District, West Wellega (Ethiopia). Ethiopian Journal of Animal Production 2(1): 97-114.

Lema, F. (2004). Assessment of butter quality and butter making efficiency of new charns compared to smallholders'butter making techniques in east showa zone of Oromia, Ethiopia, Msc, thesis. Alemaya Univestity of Agriculture Dire Dewa, Ethiopia.

Mekonnen, A. (2006). Women's role on production, processing and marketing of milk and milk products in Delbo watershed of Wolaita zone, Ethiopia. MSc thesis. Hawassa University, Awassa, Ethiopia. Pp.64.

Nebiyu, R. (2008). Traditional and improved milk and milk products handling practices and compositional and microbial quality of milk and buttermilk in Delbo watershed of Wolaita zone, Ethiopia. M.Sc. thesis. Hawassa University, Hawassa, Ethiopia.

Negassa, A., Rashid, S.H. and Gebremedhin, B. (2011). Development Strategy and Governance Division, International Food Policy Research Institute - Ethiopia Strategy Support Program II, Addis Ababa Ethiopia.

Olana, B.T. (2006). People and Dam: Environmental and Socio-economic changes induced by reservoir in Ficha Water shades, Western Ethiopia. Wageningen University, Netherland.
Sci. Technol. Arts Res. J., April-June 2015, 4(2): 215-221

Tesfaye, L. and Puskur, R. (2007). Understanding and Analyzing Dairy and Forage innovation system in Ethiopia. Improving productivity and Market Success(IPMS) of Ethiopian farmers project, IRLI, Addis Abeba, Ethiopia.

Tsehay Redda (2002). Small-scale milk marketing and processing in Ethiopia. 352-367 pp. In: Smallholder dairy production and market opportunity and constraints. Proceeding of south workshop held at NDDB, Anand, India, and 13-16 march 2001. NDDB (National Dairy Development Board), Anand, India, and ILRI (International Livestock Research Institute), Nairobi, Kenya.

Upton, M. and Otte, J. (2004). The Role of Livestock in the Economic Development and poverty Reduction. Pro-Poor Livestock Policy Initiative, A Living from Livestock Research Report.PPLPI,Working Paper FAO, Rome. 1-5 pp.

USAID (Unite State of America peoples Aid), (2010). The Next stage in Dairy Development for Ethiopia Dairy Value Chains, End Markets and Food Security; Cooperative Agreement 663-A-00-05-00431-00;Addis Ababa, Ethiopia.

Yigezu, Z. (2003). Imperative and Challenges of Dairy Production, Processing and Marketing in Ethiopia. Challenges and Opportunities of Livestock Marketing in Ethiopia. Proceedings of the 10th annual conference of the Ethiopian Society of Animal Production (ESAP) held in Addis Ababa, Ethiopia, August 21-23.

Yilma, Z., Guernebleich, E. and Sebsibe, A. (2011). A Review of the Ethiopian Dairy Sector.

FAO Sub Regional Office for Eastern Africa (FAO/SFE).

Yigrem, S., Beyene, F., Tegegne, A.and Gebremedhin, B. (2008). Dairy production, processing and marketing systems of Shashemene-Dilla area, South Ethiopia. Improving Productivity and Market Success (IPMS) of Ethiopian farmers' project, International Livestock Research Institute (ILRI), Addis Ababa, Ethiopia. 